UDC 37.013.2

DOI: 10.15587/2519-4984.2021.228249

\title{
PROFESSIONAL COMPETENCIES OF STUDENTS OF PHYSICAL AND MATHEMATICAL SPECIALTIES
}

\author{
Livia Mesarosh
}

The article outlines the issues of professional competence of senior students of physical and mathematical specialties. A comparative description of their professional competencies is given, common and specific components are identified. It was found that in combination with traditional pedagogical teaching methods (based on the student's reproductive activity), it is important to introduce the latest methods, which provide special attention to the formation of professional competencies of university graduates. It is substantiated that physics is inextricably linked with mathematics. Mathematics gives physics the means and techniques of general and accurate expression of the relationship between physical quantities, which are discovered as a result of experiment or theoretical research. Therefore, the content and methods of teaching physics depend on the level of mathematical training. It is shown that the teaching of physics and mathematics should be based on the mutual use of elements of mathematics in the course of physics and physical concepts in the study of algebra and the principles of analysis, because it accelerates mental development and formation of scientific worldview of students. The importance of interdisciplinary connections as a component of interdisciplinary integration in order to optimize the educational process is revealed. The question of possibilities of creation of physical and mathematical discipline and a set of competences which future experts should possess is considered. It was found out that for future specialists such an approach would allow to carry out the educational process in accordance with the requirements of modern dynamic educational space, acquire new skills, be more competitive, but at the same time due to a large number of discrepancies in the competences of physics and mathematics

Keywords: professional competence, scientific worldview, interdisciplinary connections, critical thinking, higher education

How to Cite:

Mesarosh, L. (2021). Professional competencies of students of physical and mathematical specialties. ScienceRise: Pedagogical Education, 2 (41), 31-34. doi: http://doi.org/10.15587/2519-4984.2021.228249

(C) The Author(s) 2021

This is an open access article under the CC BY license (http://creativecommons.org/licenses/by/4.0).

\section{Introduction}

Higher education is in the midst of a major transformation. The latest training systems aim to shorten the learning curve by optimizing the learning curve. Focusing on the basic and essential in the educational material, the establishment of interdisciplinary connections between professional disciplines is an important component of the concept of interdisciplinary integration. One of the possible directions of modernization of educational production envisages the creation of physical and mathematical science. Physics and mathematics have certain analogies, creates the prerequisites for a deep understanding by students of the methodology for solving problems in the physics and mathematics cycle. When solving problems, the connection between the mathematical expression and the physical content of the equation or theorem with theoretical justification, ensuring better assimilation by the student. A certain level of understanding of the material is required to memorize it.

The dynamics of changes in professional competencies is increasing. In recent studies, it is emphasized that any specialist in the near future is doomed to constant replenishment, updating of their skills and abilities. In such conditions, the readiness for continuous self- education and self-development is the most important condition for maintaining the competitiveness of a specialist [1]. According to the new standards and indicators of quality and the development of new information and educational technologies, such competencies will play an increasingly important role: deep knowledge of the specialty, analytical thinking, the ability to quickly master new information, negotiate, work in a stressful situation, effectively use working time, work in a team, competently express their thoughts, own modern information technologies [2].

\section{Literature review}

According to [3], competence is the ability to successfully meet individual or social needs, to carry out activities or to perform assigned tasks. However, the author of work [1] notes that competence is a little more, a quality that appears as a result of the prevailing specific knowledge, skills and abilities that a graduate must possess upon graduation from a university. Competencies, in turn, constituting competence, form in the process of obtaining higher education a certain range of knowledge, skills, and abilities that should be possessed. Competencies are described using standards and criteria for per- 
forming tasks or behavioral standards, characterizing the activity capabilities of an individual in the social context of activity.

Competence is an integrative characteristic of a person, it is a holistic, systemic set of qualities necessary for the successful performance of activities in certain areas: the so-called competencies, as well as the ability to effectively solve problem situations and tasks that arise in all other spheres of its life. Professional competence is considered as the most important component of professional education, as an integral characteristic of the personal and active qualities of a future specialist, reflects the level of his knowledge, skills and experience sufficient to achieve the goals of professional activity and the social position of the individual [4].

The competence-based approach in vocational education consists in developing a set of key competencies among students, which they will further apply for successful activities in a particular professional field. The competencebased approach in education establishes a new type of educational results, is not limited to a combination of knowledge and skills, but is focused on the ability and readiness of an individual to solve various kinds of problems. The concept of "competence" includes knowledge, skills and abilities, personal qualities (initiative, commitment, responsibility, tolerance, etc.), social adaptation (the ability to work independently and in a team) and professional experience. These components allow the graduate to learn how to navigate the situation, correctly set and solve the tasks assigned to him $[5,6]$. The following components of competence can be distinguished [7]:

1. procedural competence - the ability to interpret the results of certain measurements in the form of statistical tables, diagrams, graphs, etc., the ability to "read" tables, diagrams, graphs of functions, to use the apparatus of mathematical analysis and statistics;

2. logical competence - possession of inductive and deductive methods of reasoning, argumentation, proof and refutation of statements, possession of general methods of mental activity in the field of special object objects: methods of analysis, synthesis, comparison, classification, abstraction, generalization, concretization, establishment of analogies; the use of causal, structural and logical, system-educational links;

3. technological competence - possession of modern mathematical packages, technologies for building diagrams, graphs;

4. research competence -the ability of a subject to independently master or create systems of new knowledge as a result of a shift in emphasis in activity from functional to transformative, based on a system of previously mastered knowledge, skills, and abilities;

5. methodological competence - mastering universal methods of cognitive activity, critical analysis of the feasibility and effectiveness of each of them, the ability to assess the feasibility and features of the use of mathematical methods in the professional field, in order to solve professional applied problems.

Natural-scientific competence involves mastering the terminological apparatus of the natural sciences, mastering subject knowledge and understanding the essence of the basic laws and patterns that make it possible to understand the course of natural phenomena and process- es; understanding of fundamental ideas and principles of natural sciences; gaining experience in practical and experimental activities, the ability to apply knowledge in the process of learning about the world; the formation of value orientations for the preservation of nature, the harmonious interaction of man and nature, and the idea of sustainable development $[8,9]$.

\section{The aim and objectives of research}

The aim of research is to develop and practically test the technology for the formation of professional competencies of students of physicists and mathematicians, effective methods, forms and means of teaching using intersubject connections to increase the effectiveness of teaching subjects of the natural and mathematical cycle, the intellectual development of students and the formation of sustainable cognitive interests in their field.

To achieve the aim, the following objectives are set:

1. Analyze scientific works devoted to the formation of professional competencies of students of physicists and mathematicians, taking into account the presence of intersubject connections.

2. To identify general and specific characteristics of professional competencies.

3. Determine (on the basis of analysis) the possibilities and feasibility of creating physical and mathematical science.

\section{Methods of research}

To achieve the aim of research, empirical methods were used: observation of the educational process of students while teaching physics and mathematics, analysis of the results of educational achievements of students. A set of methods of scientific knowledge were effectively used: a systematic and comparative analysis of literature, work programs, the pedagogical process on the problem of research, generalization and systematization of scientific and theoretical provisions in order to obtain a holistic picture of the current state of research and the possibilities of improving approaches to the issue of professional competencies.

\section{Research results and their discussion}

According to the results of research by psychologists, intersubject associations have a positive effect on the development of imagination, observation, memory, speech, form the ability to abstract thinking and to independently transfer knowledge, skills and abilities to new cognitive tasks. It is this independence that is called "the most important indicator of mental development" [9]. One of the main conditions for the formation of a student's professional competence in the learning process should be his self-identification as a subject of educational activity, the purpose of which is the consistent acquisition of knowledge, skills and abilities. Only selforganization, self-control will allow the student to become competent in the specialty being received [1]. Choosing a profession, a student must clearly understand what the requirements for him will be in the future, it is important to have an idea of the rights and obligations of a specialist of the chosen qualification. 
The goal of training physicists is to train specialists who are able to theoretically interpret and experimentally study the physical laws of fundamental natural phenomena, simulate complex processes, develop and operate high-quality equipment and measuring instruments. The purpose of training mathematicians is to train specialists who are able to use the acquired mathematical knowledge in practice, are able to model both theoretical and practical mathematical problems, and develop methods for solving such problems.

Although the process of mutual penetration and communication between the sciences is clearly outlined in the modern system of sciences, students of all specialties and areas of training should have general professional competencies:

- Possess deep and solid professional knowledge, the application of which is necessary to solve practical problems.

- Ability to constantly improve their knowledge, acquire new skills.

- Possess the culture of written and oral speech, competently express their thoughts, be able to present their point of view with arguments.

- Ability to cooperate responsibly with specialists and non-specialists in their own / related industry.

- Ability to use the knowledge gained to distinguish between scientifically based and unsubstantiated claims in their field.

- Ability for professional development, professional development and commitment to quality work.
- Ability to navigate the most important aspects of the history of science and awareness of possible directions of development and the state of modern science.

- Awareness of the literature of your industry.

- Knowledge of environmental awareness.

- Knowledge of communication in a foreign language.

- Possession of work skills in accordance with the requirements of the modern information space.

It should be noted that the EU countries emphasize the importance of such competencies as lifelong learning and maintaining contact with the values of national culture and Europeanness [10,11]. Analyzing the curricula, it can be seen that the modern education system is built in such a way that mathematicians and physicists have many common academic subjects, both professional and general. In order to find out the general and specific features of the activity of a physicist and a mathematician, let's define their professional competencies (Fig. 1.). In the general case, the basic competencies of students should be laid down in the general education system, and in the system of higher professional education, it is professional competencies that should be formed. From the analysis of Fig. 1 it can be seen that a physics student studies nature from the point of view of science and modern technologies, is able to apply the knowledge gained in practice, observe, analyze, formulate hypotheses, conduct experiments, analyze results. A senior mathematician in the learning process could develop abstract thinking and is able to use it in various fields of activity, is capable of modeling, analysis, systematization, etc.

\section{Student competencies}

\section{physicist}

1. Knows basic physical phenomena and fundamental physical concepts; laws and theories of classical and modern physics

2. Recognizes the physical laws of natural phenomena, is able to theoretically interpret them for scientific purposes.

3. Knows about the new achievements of modern physics and knows how to apply them as often as possible.

4. Knows methods of theoretical, experimental physics, mathematical and computer processing of information.

5. Knows modern research instruments and the basic principles of their work.

6. Knows how to use laboratory and practical materials, tools and methods related to physics, with the help of which he can pursue his profession at a high level.

7. Able to design, perform and evaluate experiments based on in-depth knowledge of the physical sciences.

8. Able to design and operate industrial, information and measurement systems based on physical laws and high-tech processes.

9. Thanks to regular professional self-education, he is able to process new scientific results of physics and creatively apply them in its work.

10. Able to check the investigated processes and systems of his industry using methods adopted in the practice of physical sciences.

11. Able to formulate scientific questions related to physics and related fields.

Fig. 1. Comparison of professional competencies of senior students of physical and mathematical specialties mathematician

1. Knows the methods of mathematical science at the system level and in their context in the field of analysis, algebra, number theory, geometry, discrete mathematics, probability theory (mathematical statistics)

2. Possesses abstract mathematical thinking, mathematical conceptualization 3. Possessing a high level of mathematical knowledge, it independently chooses methods for solving problems.

4. Realizes the importance of mathematical thinking and accurate conceptualization, and formulates its opinion with this in mind.

5. Knows the principles and methods of mathematical proofs.

6. Able to apply abstract thought processes, methods and concepts acquired in mathematics in new areas of research and to achieve new scientific results.

7. Able to create mathematical models of environmental phenomena, use the results of modern mathematics to explain and describe these phenomena.

8. Able to record the connections observed in practical life at an abstract level.

9. Realizes that the special vision it received while teaching mathematics can help in solving problems in an innovative way that arise in other fields of science.

10. Capable of transforming data from various sources using information processes, use digital technologies in the educational process in the field of mathematics.

\section{Conclusions}

1. In conclusion, it should be said that the analysis of scientific works on the formation of professional com- petencies of students of physicists and mathematicians was carried out, taking into account the presence of interdisciplinary connections, because the requirements for 
specialists are constantly growing, the emergence of online technologies, the possibility of participation in foreign projects, the acceleration of the pace of life require a competent approach.

2. General and specific characteristics of professional competencies of students of physics and mathematics are revealed.

3. The possibilities and expediency of creating physical and mathematical science are determined (on the basis of analysis). When optimizing educational processes, the goal of training will change, and the employment opportunities for university graduates will expand. But such specialists will have to possess the competencies of both specialties, and, as can be seen from the analysis of the results, there are significant differences among the competences of the abovementioned specialties.

Rethinking the tasks and principles of activity in educational spaces on this issue leaves a number of methodological questions for itself.

\section{References}

1. Simaeva, N. P. (2010). Professional the competence of students of economic and legal specialities: the general and especial in the contents and formation conditions. Vestnik VolGU, 12, 50-59.

2. Wong, A. Y., Daud, K. (2018). ICT Competencies among School Teachers: A Review of Literature. Journal of Education and Learning, 12 (3), 376-381. doi: http://doi.org/10.11591/edulearn.v12i3.5579

3. Foxon, M., Richey, R. C., Roberts, R. C., Spannaus, T. W. (2003). Training Manager Competencie. ERIC Clearinghouse on Information and Technology, 177.

4. Zhalinskii, A. E. (2009). Vvedenie v spetsialnost «IUrisprudentsiia». Professionalnaia deiatelnost iurista. Moscow: Prospekt, 368.

5. Ostanina, S. A., Ptitsyna, E. V. (2019). Competence approach to teaching University students in conditions implementation of educational standards of the third generation. World of Science. Pedagogy and psychology, 5, 1-12.

6. Febrianis, I., Muljono, P., Susanto, D. (2014). Pedagogical competence-based Training Needs Analysis for Natural Science Teachers. Journal of Education and Learning, 8 (2), 144-151. doi: http://doi.org/10.11591/edulearn.v8i2.216

7. Rakov, S. A. (2005). Formuvannia matematychnykh kompetentnostei vypusknyka shkoly yak misiia matematychnoi osvity. Matematyka v shkoli, 5, 2-8.

8. Neporozhnia, L. V. (2016). Methodical features of formation of natural and scientific competence of seniors at physics lessons. Zb. nauk. prats. Seriia: Pedahohika, 22, 96-99.

9. Mantula, T. I. (2005). Integrirovannoe prepodavanie i mezhpredmetnye sviazi v istoricheskom aspekte i segodnia. Visnik Zhitomirskogo derzhavnogo universitetu, 21, 95-99.

10. Csilla, D. T. Kompetenciákról általánosságban. Available at: https://gramontinternational.com/hu/kompetenciakrolaltalanossagban

11. Zoltán, N. (2017). Közép-kelet európai generációk digitális kompetencia és biztonságtudatosság vizsgálatának eredményei. Hadmérnök, 12 (4), 159-172.

Received date 09.02.2021

Accepted date 19.03.2021

Published date 31.03.2021

Livia Mesarosh, PhD, Associate Professor, Department of Mathematics and Informatics, Ferenc Rákoczi II Transcarpathian Hungarian College of Higher Education, Kossuth sq., 6, Beregszász, Ukraine, 90200

E-mail: liviamesarosh@gmail.com 